Jerzy Kostorz

The University of Opole, Poland

\title{
Introducing Teenagers to a Dialogue with Judaism as the Task of School Catechesis
}

\begin{abstract}
This analysis proves that introducing teenagers to a dialogue with Judaism is one of catechesis's tasks. This task has been outlined in the post-conciliar documents of the Catholic Church. It underlines the spiritual ties between Catholic people and the Jews and promotes forming an attitude of openness towards followers of the Mosaic religion. It also contributes to mitigating anti-Semitism among Catholic teenagers. At the same time, it raises interest in Jewish traditions and culture. In the religion syllabus in lower and post-secondary schools we can come across numerous references (mainly indirect) to Judaism. The focus on passing honest knowledge about Judaism can be also clearly visible. In this way, formation of the cognitive element of interreligious dialogue takes place. On the other hand, less attention is devoted to other components of this attitude such as the emotional and behavioural elements. That is why there is a demand to complete the lacking elements by watching films and having discussions. The above mentioned multimedia materials called "The religion lesson" have been prepared to satisfy this need.

Great importance is also attached to creating situations that allow Christian teenagers to participate in meetings with the Jews. It can be organized in the form of Days of Judaism and panel discussions with Jews and distinguished contemporary theologians and philosophers. Open meetings with representatives of Judaism are a great opportunity to perceive the Jews as "older brethren in the faith". They let young people discover the cultural wealth and vision of Judaism and teach teenagers respect for the religious beliefs of the Jews. Thereby, they can contribute to the change of mentality of young participants of catechesis in their approach to Judaism. It is worth referring to the works of Jewish culture in these activities. It is the cultural heritage that comprises a great reference point to showing the strong Judaic roots of Christian culture. Thus, it is necessary, for the topics in Judaism proposed for religious syllabuses and catechetical material to be
\end{abstract}




\section{The Person and the Challenges \\ 128

closely connected with organizing meetings of young Catholics with followers of the Mosaic religion. Only this kind of experience can contribute to an authentic inter-religious dialogue.

\section{Keywords}

Catholicism, Judaism, catechesis, dialogue, teenagers.

Various tasks are undertaken within the framework of catechetical activity at school. They can be divided into three groups. Didactic tasks constitute the first group. They relate to the systematic comprehensive teaching of Christian doctrine ${ }^{1}$. Next, there are evangelical tasks ${ }^{2}$ connected with preaching the Good News. Educational tasks ${ }^{3}$ are also very important. They concern developing the skills and forming social, moral and religious attitudes, as well as preparing pupils for life, integrating culture and faith, enabling the internalization of the values underlying Christianity, and instilling tolerance ${ }^{4}$. A significant part of these tasks is introducing teenagers to a dialogue with Judaism. It is directly connected with ecumenical education in a broad sense. School catechesis, conveying the message of salvation, ought to teach teenagers dialogue with followers of different religions and Christian communities ${ }^{5}$. The reference to the followers of Moses cannot be missed here. The issue of Judaism has been very popular recently. Apart from anti-Semitic attitudes, a very positive openness towards the Jewish culture and religion can be observed ${ }^{6}$. There is also an increasing interest in Judaism? ${ }^{7}$. This situation implies the need to

1 Catechesi tradendae 18.

2 Konferencja Episkopatu Polski, Dyrektorium Katechetyczne Kościoła Katolickiego w Polsce, Kraków 2001, 54-56, 84.

3 Konferencja Episkopatu Polski, Dyrektorium Katechetyczne..., 83; J. Stala, Richtungsweisende Merkmale zur religiösen Erziehung und Bildung im Lehrwerk von Papst Johannes Paul II., „Bogoslovska Smotra“ (2014) Nr 1, p. 137-148; J. Stala, Katechese im Zeitalter der Postmoderne. „Grundsatzprogramm für die Katechese der Kirche in Polen“ aus dem Jahr 2010, „Bogoslovni vestnik“ 74 (2014) Nr 1, p. 107-117.

4 Konferencja Episkopatu Polski, Dyrektorium Katechetyczne..., 85.

5 Konferencja Episkopatu Polski, Dyrektorium Katechetyczne, 26, 30, 74, 86, 99, 133, 139, 197-198, 200.

6 See K. Pilarczyk (ed.), Żydzi i judaizm we współczesnych badaniach polskich, vol. IV, Kraków 2008; K. Pilarczyk (ed.), Żydzi i judaizm we wspótczesnych badaniach polskich, vol. 5.

7 See S. Górzna, Dzieci Abrahama: dialog Kościoła katolickiego z islamem i judaizmem w Polsce w okresie pontyfikatu Jana Pawła II, Słupsk 2013; L. A. Wawrzyńska-Furman, Judaizm a ekumenizm w świetle nauczania Jana Pawła II, Toruń 2009. 
introduce teenagers to a dialogue with the followers of Moses. Such a task cannot be fulfilled without school catechesis.

The intention of the author of this article is to discuss the issues that relate to introducing teenagers, during school catechesis, to a dialogue with Judaism. To accomplish this task a catechist is required to have knowledge about the essence of a dialogue between Christianity and Judaism and must be familiar with catechetical materials that contain numerous references to the religion of Moses. Taking this into account, the aforementioned issues will be discussed. The instruction of the Roman Catholic Church in a dialogue between Christianity and Judaism will be a reference point. Attention will also be devoted to materials from "Religion lessons" series which aim at forming the attitude of dialogue not only with Christians but also with followers of different religions including Judaism.

\section{A contemporary dialogue of the Roman Catholic Church with Judaism}

The dialogue that is currently being led between the Roman Catholic Church and Judaism is based on the instruction of The Second Vatican Council. This Council played a decisive role in understanding the ties between the Roman Catholic Church and the Jewish nation and religion. It has also depicted the common history of Christians and the Jews ${ }^{8}$.

The conciliar declaration on the Church's attitude towards non-Christian religions Nostra Aetate $^{9}$, issued on $28^{\text {th }}$ October 1965, had a valuable contribution to a dialogue of Christians with Judaism. The common spiritual heritage of Christians and the Jews was mentioned there. The figure of Abraham ${ }^{10}$ was evoked by the fathers of the Second Vatican Council.

8 See M. Czajkowski, 40 lat minęło od ogłoszenia ,Nostra Aetate”, in: K. Konecki, Z. Pawlak, K. Rulka (eds.), Teologia Ekumenizmu. Kultura, Włocławek 2006, p. 266-272.

9 M. Czajkowski, 40 lat minęlo od ogloszenia „Nostra Aetate”,p. 266-272; comp. Sobór Watykański II, Deklaracja o stosunku Kościoła do religii niechrześcijańskich Nostra aetate, in: Sobór Watykański II, Konstytucje, dekrety, deklaracje, Poznań 2002, p. 327-337.

${ }^{10}$ M. Czajkowski, 40 lat minęto od ogłoszenia „Nostra Aetate”, p. 266-272; comp. Sobór Watykański II, Deklaracja o stosunku Kościoła do religii niechrześcijańskich Nostra aetate, in: Sobór Watykański II, Konstytucje, dekrety, deklaracje, Poznań 2002,327-337. 


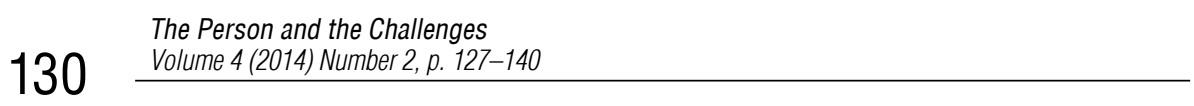

The post-conciliar dialogue of the Roman Catholic Church with Judaism is religious and theological in its character ${ }^{11}$. It also refers to the Nazi holocaust of the Jews that happened during World War II in Europe. In Nostra Aetate, the council Fathers reminded that "the Church (...) disapproves of any oppression" 12 of people and "remembering the common heritage with the Jews grieves over all acts of hate, persecution, all manifestations of anti-Semitism that occurred in any time during the war and from any people"13. They also encouraged all Christians and Jews to mutual appreciation and respect that can be achieved through biblical and theological studies and brotherly dialogues ${ }^{14}$.

According to the recommendations of the Second Vatican Council, the dialogue of the Roman Catholic Church with Judaism has been inscribed in its ecumenical activity. The evidence of it is the formation (in 1966), in the framework of Secretariat for Promoting Christian Unity of the Commission for Religious Relations with the Jews ${ }^{15}$. The Jews also created (in 1970) The International Jewish Committee for Interreligious Consultations within the headquarters in New York and Geneva ${ }^{16}$. Next, the representatives of the Roman Catholic Church and Jewish organizations initiated their meetings. The International Catholic-Jewish Liaison Committee was brought into existence. It holds annual meetings and discusses various aspects of Catholic and Jewish relations. Efforts have also been made to change the Christians' attitude towards Jewish people ${ }^{17}$.

The documents from Vatican Council II are vital in the dialogue between the Roman Catholic Church and Judaism. The first of them was issued on $1^{\text {st }}$ December 1974 by The Commission of the Holy See for Religious Relations with the Jews. It is entitled "Guidelines and suggestions for implementing the conciliar declaration Nostra Aetate nr 4"18. This document, in the spirit of

${ }^{11}$ See W. Chrostowski, Na drogach dialogu Kościoła z Żydami i judaizmem, „Paedagogia Christiana" (2010) no. 2, p. 65-79.

12 Nostra Aetate, 4.

${ }_{13}$ Nostra Aetate, 4.

${ }^{14}$ Nostra Aetate, 4.

${ }^{15} \mathrm{~W}$. Chrostowski, Stan dialogu katolicko-żydowskiego $w$ perspektywie ogólnokościelnej i polskiej, www.mateusz.pl/czytelnia/wch-sdkz.htm (02.04.2014).

${ }^{16}$ W. Chrostowski, Stan dialogu katolicko-żydowskiego...

${ }^{17}$ W. Chrostowski, Stan dialogu katolicko-żydowskiego...

${ }^{18}$ Komisja do Spraw Kontaktów Religijnych z Judaizmem, Wskazówki i sugestie w sprawie wprowadzania w życie deklaracji soborowej „,Nostra aetate”, nr 4 (01.12.1974), Kraków 2003. 
the Second Vatican Council, suggests guidelines on how to hold a dialogue between Catholics and the Jews. It clearly emphasizes that a real dialogue requires respect for another human being, especially his/her faith and religion ${ }^{19}$. The successive document was published on $24^{\text {th }}$ June 1985 by the aforementioned commission. It was named "The Jews and Judaism in preaching the word of God and in catechesis of the Catholic Church. The guidelines to a proper presentation of these issues" ${ }^{20}$. The addressees of this document are priests - preachers and catechists. It contains valuable hints for people who introduce Catholic teenagers to a dialogue with Judaism. The following tips on introducing knowledge may be found there: 1) on the Jews and Judaism, 2) connections between the New and Old Testament, 3) the Jewish roots of Christianity, 4) the picture of the Jews in the Bible, mainly in the New Testament, 5) Christian liturgy that has its source in Judaism, 6) relations that need to be nurtured between Catholics and the Jews ${ }^{21}$. It must be remembered that the Jewish and Catholic traditions are very close, and that is why they ought to appreciate each other ${ }^{22}$. Such guidelines are very important for school catechesis as they show basic topics that should be present when teaching about Judaism.

However, the dialogue is not exhausted simply by conveying or having knowledge. It needs the proper style of action, the attitude of openness and respect but also the kindness towards followers of different religions and recognition of their religious identity. John Paul II underlined it many times. He also manifested through his life how this dialogue between Catholicism and Judaism should look like. On various occasions, the Pope met the Jews, for example in the former concentration camp in Auschwitz-Birkenau (1979), in the Roman synagogue (1986), in the Jjubilee Year 2000 during the pilgrimage to the Holy Land ${ }^{23}$. He used to call the Jews "beloved brothers" and "the older

${ }^{19}$ Komisja do Spraw Kontaktów Religijnych z Judaizmem, Wskazówki $i$ sugestie w sprawie wprowadzania w życie deklaracji soborowej ,, Nostra aetate”, nr 4 (01.12.1974), Kraków 2003.

${ }^{20}$ Komisja do Spraw Kontaktów Religijnych z Judaizmem, Żydzi i judaizm w gloszeniu słowa Bożego i katechezie Kościoła katolickiego. Wskazówki do właściwego przedstawiania tych zagadnień, 24 czerwca $1985 \mathrm{r}$.

${ }^{w w}$ w.archidiecezja.warszawa.pl/upload/binaries/dokumenty/dokumenty_stale/zydzi_judaizm _W_gloszeniu_slowa.pdf (02.04.2014), p. 1-10.

${ }^{21}$ Komisja do Spraw Kontaktów Religijnych z Judaizmem, Żydzi i judaizm..., p. 1-10.

${ }^{22}$ Komisja do Spraw Kontaktów Religijnych z Judaizmem, Żydzi i judaizm..., p. 1-10.

${ }^{23}$ See W. Chrostowski, Na drogach dialogu Kościoła z Żydami i judaizmem, p. 72-73. 
brothers in faith" 24 . The Pope contributed to establishing diplomatic relations between Israel and the Vatican. John Paul II made a significant contribution towards the writing of (16 ${ }^{\text {th }}$ March 1998) by The Vatican's Commission for Religious Relations with the Jews, the document entitled "We remember: A reflection on the Shoah" ${ }^{25}$. Time after time, he reminded the Catholics that anti-Semitism is a $\sin ^{26}$. Emphasizing the aforementioned facts seems to be immeasurably important for school catechesis. It underlines the need to unceasingly remind the young people that everybody deserves respect, regardless of religion, and what is more, thanks to the contact with followers of different religions, our spirituality can also enrich itself.

In Poland the dialogue of the Roman Catholic Church with Judaism takes place on many different levels. The activities supporting the dialogue between Christians and the Jews include the works of the Polish Episcopal Commission for Dialogue with Judaism and organizing ecumenical ${ }^{27}$ congresses, conferences, symposiums and meetings. The following examples can be mentioned: The International Theological Colloquium "The Jews and Christians in a dialogue" (Kraków - Tyniec, 24-27th April 1988), symposiums "The Church and the Jews and Judaism", at first organized by the Academy of Catholic Theology and currently at the Cardinal Stefan Wyszynski University in Warsaw, the establishment of Polish-Jewish Dialogue section (1990) and the Institute for Jewish-Catholic Relations (1994) ${ }^{28}$.

For the issue under discussion, which concerns introducing Catholic teenagers to a dialogue with Judaism, annual celebrations of the Day of Judaism are of great importance. They take place on the 17th January, on the eve of The Week of Prayer for Christian Unity. The Day of Judaism was established by the Conference of the Polish Episcopate in $1997^{29}$. The central celebrations are held in chosen cities. Every year the celebrations are marked by a different motto. Yet, the aim is always to discover the ties with Judaism, 2005 .

${ }^{24}$ See W. Chrostowski, Żydzi i judaizm w nauczaniu Jana Pawła II: 1978-2005, Warszawa

${ }^{25}$ See www.opoka.org.pl/biblioteka/W/WR/komisje_pontyfikalne/judaizm/pamietamy_1903 1998.html (03.04.2014).

${ }^{26}$ See excerpts of the Catholic Church documents about anti-Semitism,www.dialog.org/ dialog_pl/dok-antysem.html (03.04.2014).

${ }^{27}$ W. Chrostowski, Stan dialogu katolicko-żydowskiego..., p. 3-9.

${ }^{28}$ W. Chrostowski, Stan dialogu katolicko-żydowskiego..., p. 1-9.

${ }^{29}$ The Day of Judaism, www.brewiarz.pl/czytelnia/judaizm.php3 (03.04.2014). 
once more, by the return to the roots and to find the common heritage ${ }^{30}$. This is the only way to recognize and understand the mystery of Jesus Christ.

\section{Judaism in the syllabus of the Roman Catholic religion teaching}

The task of introducing teenagers to a dialogue with Judaism is realized in school catechesis based on religion syllabuses in lower and upper secondary schools. Currently the syllabus of the Roman Catholic religion has been in force since $2010^{31}$. The clear concern about creating in young people the attitude of dialogue among religions and religious tolerance can be observed only sporadically. The issue of Judaism can only be found in connection with the texts of the Old Testament. There are only few references to the Jewish religion both in lower and upper secondary schools. This is incomprehensible. The guidelines that can be found in "The General Catechetical Directory" from $1997^{32}$ are not taken into consideration in the religion syllabus in lower and upper secondary schools. Merely the repeated reference to the Old Testament and depicting the Church as the God's People of New Covenant may be perceived as an intention to form the attitude of dialogue with Judaism. Its' purpose is the cognition of the proper ties between Christianity and Judaism. The Jews are presented as ancestors whom the God addressed. Indirectly, in this way young people can find out a close connection of Judaism and Christianity, and have the chance to discover the ties of spiritual community of the New Convenant with Abraham's offspring ${ }^{33}$.

Precisely, in the lower secondary school syllabus there are mainly indirect references to Judaism. It is visible in the following topics: biblical prehistory, the times of patriarchs, the world of the Bible, the history of the chosen nation, the fulfillment of messianic prophecy in the person of Jesus Christ ${ }^{34}$. The basic events of the Old Testament history of salvation (e.g. the migration to the Promised Land, Babylonian captivity, Maccabean Uprising, the history

\footnotetext{
${ }^{30}$ The Day of Judaism, www.brewiarz.pl/czytelnia/judaizm.php3 (03.04.2014).

${ }^{31}$ Komisja Wychowania Katolickiego Konferencji Episkopatu Polski, Program nauczania religii rzymskokatolickiej w przedszkolach i szkołach, Kraków 2010.

32 Kongregacja ds. Duchowieństwa, Dyrektorium ogólne o katechizacji, Poznań 1998, no. 199.

${ }^{33}$ Nostra aetate, 4.

${ }^{34}$ Komisja Wychowania Katolickiego Konferencji Episkopatu Polski, Program nauczania religii rzymskokatolickiej w przedszkolach $i$ szkołach, p. 110-135.
} 
of Moses, Joshua, Samuel, Saul, David, Salomon, Maccabean brothers, the chosen prophets) are discussed in detail based on the Old Testament biblical fragments ${ }^{35}$. The correlation with history is an enrichment of these issues. The ancient civilization of Israel is pictured here. Information about the Decalogue completes this picture. When discussing specific Commandments the reference to the Old Testament is made. Teenagers are introduced to celebrating the Sabbath in the Old Testament. All these aspects can be found in the syllabus of religion education in the second class of lower secondary school $^{36}$. Formation of the cognitive element of teenagers' attitude which is indispensable in the dialogue of young Christians with Judaism takes place in this way. The knowledge contained in the religion textbooks helps the pupils to understand the beginnings of The Roman Catholic Church and to get to know and understand better the Jewish religion - our brethren in the faith. This understanding is meaningful in forming the attitude of religious tolerance. This aim is emphasized in the third class of a lower secondary school ${ }^{37}$.

The continuation of proposals connected with introducing teenagers to a dialogue with Judaism can be noticed in secondary, technical and vocational schools. In post-secondary schools there are also references to biblical texts of the Old Testament ${ }^{38}$. Their aim is to show the roots of Christianity. The references to the life and teaching of John Paul II and his attitude during pilgrimages $^{39}$ are worth underlining. The textbooks mention two most important meetings with followers of Jewish religion. By presenting different kinds of prayer based on the example of psalms, young people can discover the forms of prayer that is common to Catholic people and the Jews ${ }^{40}$. In the second class of lower secondary school the interpretation of the God's

${ }^{35}$ Komisja Wychowania Katolickiego Konferencji Episkopatu Polski, Program nauczania religii..., p. 110-135.

${ }^{36}$ Komisja Wychowania Katolickiego Konferencji Episkopatu Polski, Program nauczania religii..., p. 122-124.

${ }^{37}$ Komisja Wychowania Katolickiego Konferencji Episkopatu Polski, Program nauczania religii..., p. 133.

${ }^{38}$ Komisja Wychowania Katolickiego Konferencji Episkopatu Polski, Program nauczania religii..., p. 139-223.

${ }^{39}$ Komisja Wychowania Katolickiego Konferencji Episkopatu Polski, Program nauczania religii..., p. 145.

${ }^{40}$ Komisja Wychowania Katolickiego Konferencji Episkopatu Polski, Program nauczania religii..., p. 148 . 
name "I am who I am" (Book of Exodus 3,14) ${ }^{41}$ and picturing Judaism as a monotheistic religion is proposed ${ }^{42}$. The issue of inter-religious dialogue and religious tolerance are also noteworthy. They allow extending the knowledge that is necessary in the process of introducing teenagers to a dialogue with Judaism. The consideration of the aforementioned topics are completed with the reference - in relation with Polish language - to the Torah and Jewish Holy Books. Next, in parallel with the knowledge about culture, the Jewish culture and the Christian-Jewish dialogue is discussed with regards to Polish experiences ${ }^{43}$. Presenting the Jewish monuments in the region is also proposed $^{44}$. Similar topics can also be found in the syllabus of a technical school. However, they have been itemized in a different way in the syllabus since the aforementioned aspects appear mainly in the third class ${ }^{45}$. This is understandable because catechesis in a technical school lasts 4 years, like all general education. Yet in a vocational school the issues referring to Judaism have been limited to a minimum. This is due toa shorter educational span as well as the learners' capabilities and skills. The information about Jewish religion emerges in the context of other religions ${ }^{46}$. It has also been planned to show what the inter-religious dialogue is about ${ }^{47}$. These topics are to be raised, according to the syllabus, in the first class.

Consequently, it may be recognized that in the elaborated religion syllabuses in lower secondary and post secondary schools great attention has been paid to the knowledge about Jewish religion. This knowledge comprises one of the crucial elements of the attitude of dialogue between Christians and the Jews. It determines the correct cognitive component. However, knowledge itself

${ }^{41}$ Komisja Wychowania Katolickiego Konferencji Episkopatu Polski, Program nauczania religii..., p. 152.

${ }^{42}$ Komisja Wychowania Katolickiego Konferencji Episkopatu Polski, Program nauczania religii..., p. 143.

${ }^{43}$ Komisja Wychowania Katolickiego Konferencji Episkopatu Polski, Program nauczania religii..., p. 152-153.

${ }^{44}$ Komisja Wychowania Katolickiego Konferencji Episkopatu Polski, Program nauczania religii..., p. 53.

${ }^{45}$ Komisja Wychowania Katolickiego Konferencji Episkopatu Polski, Program nauczania religii..., p. 192,194.

${ }^{46}$ Komisja Wychowania Katolickiego Konferencji Episkopatu Polski, Program nauczania religii..., p. 211.

${ }^{47}$ Komisja Wychowania Katolickiego Konferencji Episkopatu Polski, Program nauczania religii..., p. 211. 
does not suffice. Introducing teenagers to a dialogue with Judaism requires developing the right skills. These comprise: respect for another human being and his/her religion; the ability to listen to the followers of Jewish religion; understanding their cultural and religious distinctness; discovering the common heritage, participation in common prayers and conferences; and exchange of opinions. All these are of great importance. It is also hard to imagine a dialogue of Catholic people and Judaism without mutual kindness and treating each other with respect. The ability to cooperate in mutually approaching each other on the spiritual level must also be recognized as very important. Religious tolerance, that is alienated from anti-Semitism, is visible in all of these activities.

\section{The dialogue with Judaism in multimedia materials of "The religion lesson"}

Multimedia materials released by the Publishing House "Saint Adalbert" and Religion TV channel seem to be helpful in the process of introducing teenagers to a dialogue with Judaism. This series has been entitled "The religion lesson". The specific materials contain a DVD with short didactic films (each on a different topic) and catechetical proposals developed to accompany them (in the form of a scenario). The scenarios of catechesis with DVDs make an innovative teaching resource during school catechesis (mainly in post secondary schools). These materials include doctrinal aspects, typical for specific Christian communities, that are presented in an interesting way. A significant value of this innovative series is depicting, the instruction of the Roman Catholic Church and the attitude of other churches and Christian communities, about the Jewish religion. When discussing various topics the reference to Judaism takes place. "The religion lesson 5 " and "The sacred books" 48 can be mentioned here. They were elaborated by A. Bałoniak and A. Zellma. The proposal of a catechetical individual devoted to sacred books ${ }^{49}$ can be found there. The authors pay a lot of attention

${ }^{48}$ A. Bałoniak, A. Zellma, Lekcja religii 5. Księgi święte, Scenariusze lekcji religii do filmów, Poznań 2011.

49 A. Bałoniak, A. Zellma, Lekcja religii 5. Księgi święte..., p. 7-15. 
to the Torah and the Talmud ${ }^{50}$. The pupils can become familiar with these books. They can also discover the similarities and differences between the Bible and apocrypha and the Talmud ${ }^{51}$. Young people are also encouraged to a dialogue with followers of Jewish religion, especially during brotherly conversations and meetings.

To instil the attitude of inter-religious dialogue with followers of Judaism within young people, parts 4 and 9 of "The religion lesson" also seem to be of importance. Part 4 has been entitled "An inter-religious dialogue" The scheduled catechesis scenarios are to increase teenagers' interest in the inter-religious dialogue proposed also by followers of Judaism. They present the tenet of building this inter-religious dialogue between Christians and the Jews ${ }^{53}$. They display the Christian and Jewish perception of $\mathrm{God}^{54}$. The similarities and differences in professing Christian and Jewish religion are emphasized. They also raise teenagers' awareness of a different approach to Jesus Christ by the Jews and Christians ${ }^{55}$. This way of conveying information should be the basis in leading a dialogue with Judaism. Thanks to the acquired knowledge, learners will be able to better understand the common heritage and the roots of Christian faith. The scenarios that deal with significant matters like ethics ${ }^{56}$, sexuality ${ }^{57}$, prayer $^{58}$, fasting ${ }^{59}$, in which we also find the reference to Judaism, complement these aspects. In the aforementioned materials, there are only references to Jewish moral principles and the way they treat specific practices. The depicted issues complete teenagers' knowledge of Jewish faith, moral principles and religious practices.

${ }^{50}$ A. Bałoniak, A. Zellma, Lekcja religii 5. Księgi święte..., p. 16-24.

${ }^{51}$ A. Bałoniak, A. Zellma, Lekcja religii 5. Księgi święte..., p. 35-61.

${ }^{52}$ M. Jański, M. Tykfer, Lekcja religii 4. Dialog międzyreligijny, Scenariusze lekcji religii do filmów, Poznań 2011.

${ }^{53}$ M. Jański, M. Tykfer, Lekcja religii 4. Dialog międzyreligijny..., p. 7-15.

${ }^{54}$ M. Jański, M. Tykfer, Lekcja religii 4. Dialog międzyreligijny..., p. 16-24.

${ }_{55}^{5}$ M. Jański, M. Tykfer, Lekcja religii 4. Dialog międzyreligijny..., p. 16-45.

${ }^{56}$ A. Bałonak, A. Zellma, Lekcja religii 11. Etyka, Scenariusze lekcji religii do filmów, Poznań 2012.

${ }^{57}$ M. Brzostowka, M. Kubiak, Lekcja religii 3. Seksualność, Scenariusze lekcji religii do filmów, Poznań 2012.

58 A. Bałoniak, Lekcje religii 13. Modlitwa, Scenariusze lekcji religii do filmów, Poznań 2013.

${ }_{59}$ M. Łukasiak, M. Mikanowicz, Lekcje religii 6. Post, Scenariusze lekcji religii do filmów, Poznań 2011. 
The materials entitled "Jewish festivals" ${ }^{60}$ seem to be the most significant for introducing teenagers to a dialogue with Judaism. They contain 6 catechesis scenarios that have been consecutively entitled: "The Pesach"61, "The Shavuot"62, "The Sukkoth and Simchat Torah"63, "The Chanukah"64, "The Purim" ${ }^{65 ",}$ and "The Holy Day"66. Topics are planned in such a way to allow one to get to know and understand the followers of Judaism. It not only gives the opportunity to discover one's own religious identity, but also enables to perceive the connections between Judaism and Christianity. Additionally, an important advantage of these catechesis scenarios is creating the attitude of inter-religious dialogue. However, the knowledge of Jewish celebrations and traditions is not enough. The ability to perceive the roots of Christianity in Judaism is indispensable. Besides, it is necessary to see the connection between Jewish and Christian celebrations. It also requires acceptance and respect for the Jews. Only then, the values and religious traditions that unite the Jews and Christians can be sought.

Consequently, the aforementioned catechetical materials may help young people to find out more about Judaism. They present an honest picture of the Jews and Judaism. They picture existing differences and similarities between Judaism and Christianity and contain proposals to evaluate Jewish values and traditions. It, in turn, fosters the development of skills of the inter-religious dialogue and helps to discover the proper ties between Christians and the Jewish nation. On this basis, young people can be taught religious tolerance, objectivity through the understanding and discussion of religious issues.

${ }^{60}$ J. Bartoszyńska, T. Siuda, Lekcje religii 9. Święta Żydowskie, Scenariusze lekcji religii do filmów, Poznań 2012.

${ }^{61}$ J. Bartoszyńska, T. Siuda, Lekcje Religii 9, Święta Żydowskie..., p. 97-14.

${ }^{62}$ J. Bartoszyńska, T. Siuda, Lekcje Religii 9, Święta Żydowskie..., p. 15-25.

${ }^{63}$ J. Bartoszyńska, T. Siuda, Lekcje Religii 9, Święta Żydowskie..., p. 26-31.

${ }^{64}$ J. Bartoszyńska, T. Siuda, Lekcje Religii 9, Święta Żydowskie..., p. 32-40.

${ }^{65}$ J. Bartoszyńska, T. Siuda, Lekcje Religii 9, Święta Żydowskie..., p. 41-48.

${ }^{66}$ J. Bartoszyńska, T. Siuda, Lekcje Religii 9, Święta Żydowskie..., p. 49-57. 


\section{Bibliography}

Bałonak A., Zellma A., Lekcja religii 11. Etyka, Scenariusze lekcji religii do filmów, Poznań 2012.

Bałoniak A., Lekcje religii 13. Modlitwa, Scenariusze lekcji religii do filmów, Poznań 2013.

Bałoniak A., Zellma A., Lekcja religii 5. Księgi święte, Scenariusze lekcji religii do filmów, Poznań 2011.

Bartoszyńska J., Siuda T., Lekcje religii 9. Święta Żydowskie, Scenariusze lekcji religii do filmów, Poznań 2012.

Brzostowka M., Kubiak M., Lekcja religii 3. Seksualność, Scenariusze lekcji religii do filmów, Poznań 2012.

Chrostowski W., Na drogach dialogu Kościoła z Żydami i judaizmem, „Paedagogia Christiana" (2010), no. 2.

Chrostowski W., Stan dialogu katolicko-żydowskiego w perspektywie ogólnokościelnej i polskiej, www.mateusz.pl/czytelnia/wch-sdkz.htm (02.04.2014).

Chrostowski W., Żydzi i judaizm w nauczaniu Jana Pawła II: 1978-2005, Warszawa 2005.

Czajkowski M., 40 lat minęto od ogtoszenia „,Nostra Aetate”, in: K. Konecki, Z. Pawlak, K.

Górzna S., Dzieci Abrahama: dialog Kościoła katolickiego z islamem i judaizmem w Polsce w okresie pontyfikatu Jana Pawła II, Słupsk 2013.

Jański M., Tykfer M., Lekcja religii 4. Dialog międzyreligijny, Scenariusze lekcji religii do filmów, Poznań 2011.

John Paul II, Posynodalna adhortacja apostolska o katechizacji w naszych czasach Catechesi tradendae (from 16 X 1979).

Komisja do Spraw Kontaktów Religijnych z Judaizmem, Wskazówki i sugestie w sprawie wprowadzania $w$ życie deklaracji soborowej „,Nostra aetate”, $\mathrm{nr} 4$ (01.12.1974), Kraków 2003.

Komisja do Spraw Kontaktów Religijnych z Judaizmem, Żydzi i judaizm w głoszeniu słowa Bożego i katechezie Kościoła katolickiego. Wskazówkido właściwego przedstawiania tych zagadnień (24.06.1985) www.archidiecezja.warszawa.pl/upload/binaries/dokumenty/do kumenty_stale/zydzi_judaizm_w_gloszeniu_slowa.pdf (02.04.2014).

Komisja Wychowania Katolickiego Konferencji Episkopatu Polski, Program nauczania religii rzymskokatolickiej w przedszkolach i szkołach, Kraków 2010.

Konferencja Episkopatu Polski, Dyrektorium Katechetyczne Kościoła Katolickiego w Polsce, Kraków 2001.

Kongregacja ds. Duchowieństwa, Dyrektorium ogólne o katechizacji, Poznań 1998.

Łukasiak M., Mikanowicz M., Lekcje religii 6. Post, Scenariusze lekcji religii do filmów, Poznań 2011.

Pilarczyk K. (ed.), Żydzi i judaizm we współczesnych badaniach polskich, vol. IV, Kraków 2008.

Rulka (eds.), Teologia Ekumenizmu. Kultura, Włocławek 2006.

Sobór Watykański II, Konstytucje, dekrety, deklaracje, Poznań 2002.

Stala J., Richtungsweisende Merkmale zur religiösen Erziehung und Bildung im Lehrwerk von Papst Johannes Paul II., „Bogoslovska Smotra“ (2014) Nr 1, p. 137-148. 
Stala J., Katechese im Zeitalter der Postmoderne. ,, Grundsatzprogramm für die Katechese der Kirche in Polen “ aus dem Jahr 2010, „Bogoslovni vestnik“ 74 (2014) Nr 1, p. 107-117.

Wawrzyńska-Furman L. A., Judaizm a ekumenizm w świetle nauczania Jana Pawła II, Toruń 2009.

www.brewiarz.pl/czytelnia/judaizm.php3 (03.04.2014).

www.dialog.org/dialog_pl/dok-antysem.html (03.04.2014).

www.opoka.org.pl/biblioteka/W/WR/komisje_pontyfikalne/judaizm/pamietamy_1903 1998.html (03.04.2014). 